\title{
A GLACIOLOGICAL MAP OF FILCHNER-RONNE ICE SHELF, ANTARCTICA
}

by

\author{
Charles Swithinbank
}

( 7 Home End, Fulbourn, Cambridge CB1 5BS, England)

Karsten Brunk

(Institut für Physische Geographie, Senckenberganlage 36, D-6000 Frankfurt am Main 1, Federal Republic of Germany)

and

Jörn Sievers

(Institut für Angewandte Geodäsie, Richard-Strauss-Allee 11, D-6000 Frankfurt am Main 70, Federal Republic of Germany)

\section{ABSTRACT}

A set of Landsat-5 multispectral scanner (MSS) images of Filchner-Ronne Ice Shelf was commissioned by the Institut für Angewandte Geodäsie and recorded over a short period in early 1986. A mosaic of digitally enhanced images was constructed, using all available ground control. In due course it is planned to use the data for the production of a series of digital-image maps at a scale of 1:1000000. Meanwhile a line map has been prepared at a scale of $1: 2000000$ to show the principal glaciological features.* The new mosaic shows much more detail than earlier Landsat images and extends coverage to higher latitudes. More of the poorly known southern boundary of the ice shelf can be identified but floating ice still extends beyond the limit of coverage. Extensive ice rumples are revealed, many of them undetected in earlier imagery. Flow bands can be tracked without a break from their ice-stream source to the ice front, over distances of up to $800 \mathrm{~km}$. Even minor tributaries, and sheet flow from the inland ice sheet between the ice streams, yield narrow but identifiable flow bands. Ice thickness, velocity, and mass-flux data are reviewed, in order to underline their dependence on good mapping.

\section{INTRODUCTION}

Ronne Ice Shelf joins Filchner Ice Shelf south of Berkner Island to form the greatest mass of floating ice in the world. Despite several pioneering journeys by American, British, and German explorers since 1957, the extent of the ice shelf as now understood owes more to interpretations of satellite imagery than to any other source. This new map should be seen as one further step, though far from a definitive step, in understanding a complex and (to some extent) enigmatic area.

Landsat image mosaics prepared in 1974 by W.R. MacDonald (of the U.S. Geological Survey) constituted the principal source for all published interpretations of the extent of the ice shelf in the period 1972-86 (Swithinbank and others 1976, Crabtree and Doake 1980, Robin and others 1983, Crabtree and Doake 1986), though several years elapsed before the mosaics themselves were published (U.S. Geological Survey 1981-82). The Landsat-5 images used to compile the new map confirm the earlier interpretations but add much new information, not only for areas imaged before but also for areas that were beyond the orbital limit of Landsats 1, 2, and 3 .

\section{FLOW BANDS}

Perhaps the most useful outcome of this project is a more positive identification of flow bands. Beside or between each ice-stream flow band is a less well-defined band derived from sheet flow. It is evident that the bulk of all the ice emanates from major ice streams; sheet flow accounts for only a small proportion of the cross-sectional area at the ice front.

All the well-defined ice-stream margins are shown on the map. The right-hand margin (facing down-stream) of Bailey Ice Stream is complicated by ice rumples and poorly differentiated from an adjoining band due to sheet flow. Slessor Glacier contributes a much broader and probably thicker flow band. Recovery Glacier has no well-defined right-hand margin because, although its principal discharge on to the ice shelf takes place west of $36^{\circ} \mathrm{W}$, a veritable cascade flows across the grounding line almost as far as the western end of Shackleton Range. The left-hand margin of Recovery Glacier abuts on to Support Force Glacier, with very little evidence of sheet flow between the two. Continuing to the west, we cannot define the right-hand margin of Foundation Ice Stream because a distributary from it appears to flow into Filchner Ice Shelf, where it merges with the product of sheet flow across the unmapped section of the grounding line between $48^{\circ}$ and $60^{\circ} \mathrm{W}$.

There is very little sheet flow across the grounding line between Möller and Institute ice streams. The principal discharge from Institute Ice Stream passes to the west of Korff Ice Rise, but a part of the discharge feeds the whole flow band between Korff and Henry ice rises. Whereas most of this band forces its way across Doake Ice Rumples, narrow bands of floating ice flow between the ice rumples and the ice rises. Hercules Inlet yields a narrow flow band that retains its identity throughout its $700 \mathrm{~km}$ journey to the ice front.

Rutford Ice Stream discharges over and to either side of Kershaw Ice Rumples. A composite flow band adjacent to it carries almost the entire sheet-flow product of Fletcher Promontory and Fowler Peninsula, together with the relatively small discharge from Carlson Inlet. Evans Ice Stream does not preserve a continuous trace of its left-hand margin, although it is probably represented by the isolated belt of crevasses between $62^{\circ}$ and $65^{\circ} \mathrm{W}$. Finally, a broad flow band off Orville Coast carries the whole product of the extensive eastern drainage from southern Palmer Land.

The ice-rise contribution to the mass flux is not easy to distinguish. However, the eastern flank of Berkner Island yields a clear flow band that is, at least north of Roberts Inlet, as wide as the mainland flow band next to it. 


\section{ICE-SHELF AREA}

The ice-shelf area on the map (including ice rises and ice rumples) is about $508000 \mathrm{~km}^{2}$. We estimate that the ice-shelf area not yet imaged by Landsat is about $15000 \mathrm{~km}^{2}$, giving an overall total of $523000 \mathrm{~km}^{2}$. Berkner Island, the largest ice rise in the world, covers $46200 \mathrm{~km}^{2}$. Henry Ice Rise covers $6600 \mathrm{~km}^{2}$, Korff Ice Rise $5700 \mathrm{~km}^{2}$, and Hemmen Ice Rise less than $100 \mathrm{~km}^{2}$. Doake Ice Rumples cover $1700 \mathrm{~km}^{2}$ out of a total ice-rumples area of about $6400 \mathrm{~km}^{2}$. Subtracting the area of ice rises and ice rumples leaves a floating ice-shelf area of $458000 \mathrm{~km}^{2}$. Although this is smaller than the area of Ross Ice Shelf as reported by Drewry (1983), it will be closer to the floating area of Ross Ice Shelf as now redefined by Shabtaie and Bentley (1987).

\section{SURFACE FEATURES}

The scale of recorded features on the ice surface varies from snow-drifts $25 \mathrm{~m}$ high caused by crevassing - for example, on Recovery Glacier (Fuchs and Hillary 1958)to flow lines represented by slopes of as little as $0.1 \%$ (Swithinbank and Lucchitta 1986). Figures $1-3$ are samples of the 66 images used to compile the map. Figure 1 shows the coast of Coats Land, together with the north-eastern corner of Filchner Ice Shelf. The giant chasm cutting diagonally across the ice shelf became the locus of a calving event of unparalleled proportions which occurred in mid-1986 (Ferrigno and Gould 1987). The chasm probably formed originally at the narrowest point of constriction of the ice shelf between Berkner Island and Coats Land. Once beyond this, a diverging flow regime dominated the

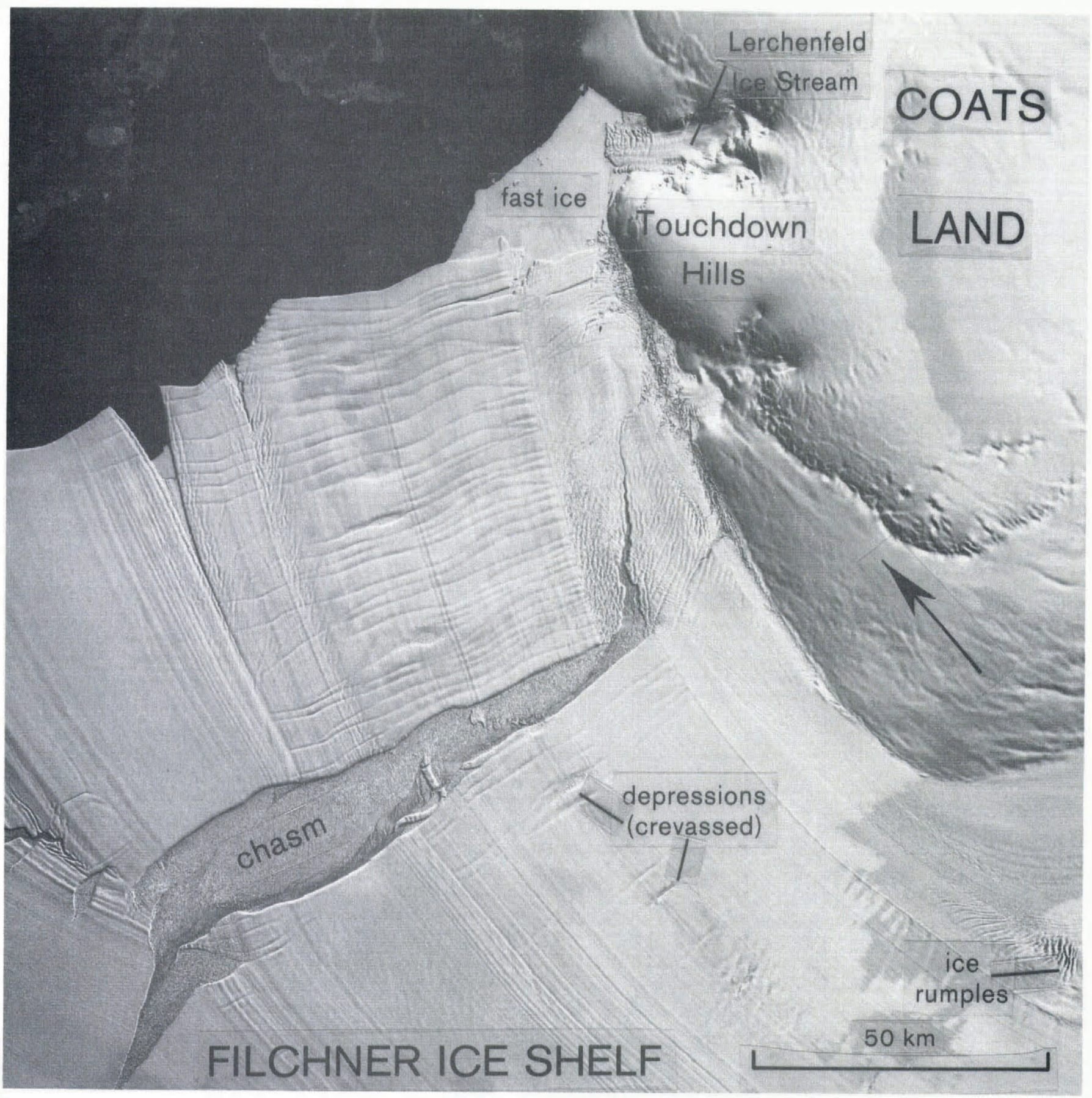

Fig. 1. Landsat-5 MSS image of Filchner Ice Shelf and Coats Land (path 185, row 116; ID 50730-09163, band 3; 1 March 1986; Sun elevation $9^{\circ}$, Sun azimuth $083^{\circ}$ ). 
flow-line pattern and the chasm progressively widened by a hinging of parts of the ice sheet with respect to flanking arms of land ice. The rifts perpendicular to the ice front are due to this kind of hinging. Neuburg and others (1959) described the chasm as "a gigantic rupture" that in 1957 was $100 \mathrm{~km}$ long and $400 \mathrm{~m}-5 \mathrm{~km}$ wide. By 1973 the rupture had grown to $115 \mathrm{~km}$ in length and was $11 \mathrm{~km}$ wide at its widest point. By February 1985 it was $19 \mathrm{~km}$ wide and three major fracture lines joined it from the sea, to herald the calving event of 1986.

In 1957 the measured depth of the chasm was $53 \mathrm{~m}$ to a bottom consisting of a chaotic confusion of ice blocks floating on the sea. Considered as freeboard, $53 \mathrm{~m}$ is close to the freeboard expected in relation to ice thicknesses of around $500 \mathrm{~m}$ that have been measured in the vicinity. North of the eastern half of the chasm is a transverse pattern of depressions with a separation of $2-4 \mathrm{~km}$ and an amplitude of about $10 \mathrm{~m}$ (Blaiklock and others 1966). Robin $(1958$, p. 120) concluded that depressions form when diverging flow is too great to be accommodated by spreading of the ice sheet in the normal course of thinning. A theoretical analysis by Collins and McCrae (1985) predicted that such depressions will form near an ice front when lateral extensional strain-rates exceed 2.3 times the longitudinal compressive strain-rate.

South of the chasm, a series of depressions (some of them obviously crevassed) reveal lines of weakness in the ice shelf. One of these may in due course provide the locus for a new chasm. Figure 1 also shows much detail on the mainland coast. Towards the top of the picture, Lerchenfeld Ice Stream (not named on the map) flows into an extensive field of fast ice. The rifted margin of Filchner Ice Shelf can be followed southwards along the foot of a gently sloping ice piedmont below Touchdown Hills. Continuing up-stream, on the right-hand margin of the picture we see one of a series of ice rumples located of the mouth of Bailey Ice Stream.

Figure 2 is one of the component images covering Ronne Ice Shelf. The northern arm of Henry Ice Rise (lower left) is flanked by small groups of ice rumples. Most

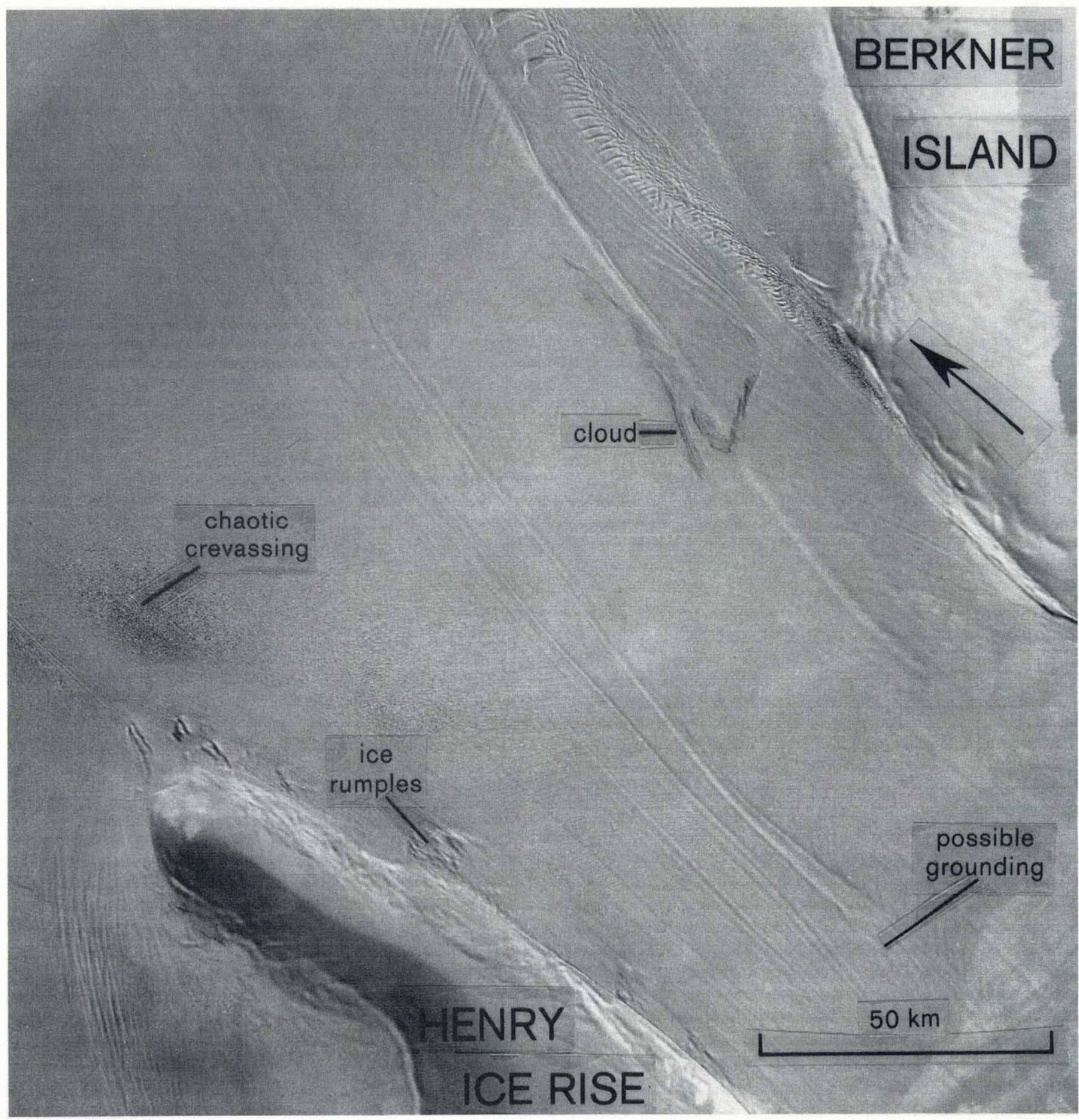

Fig. 2. Landsat-5 MSS image of Ronne Ice Shelf between Henry Ice Rise and Berkner Island (path 190, row 118; ID 50717-09483, band 3; 16 February 1986; Sun elevation $11^{\circ}$, Sun azimuth $096^{\circ}$ ). 
ice rumples may be the embryos or corpses of ice rises (Swithinbank 1986). Which they are depends on whether relative sea-level is rising or falling, and whether the ice thickness is changing with time. In due course it may be possible to recognize a morphological distinction between waxing and waning ice rumples.

Areas of disturbed ice north-east of the northern arm of Henry Ice Rise seem to be chaotically crevassed. The most conspicuous flow line cutting diagonally across the picture separates the product of Möller and Foundation ice streams. At its southern end (bottom right) some kind of diversion suggests that in places the ice could be lightly grounded. Whereas the Berkner Island grounding line is clearly defined on the right of the picture, it becomes difficult to interpret with any certainty once the complex zones of shear crevassing diverge from the main break in slope at the foot of the ice rise. The wispy dark patches to the left of this point are low cloud. On the ice rise, the two shades of grey near the margin of the picture probably represent snow surfaces of different ages; the albedo changes as new snow grains recrystallize.

Figure 3 shows the southern grounding line of Filchner Ice Shelf. Recovery Glacier bisects the picture and dominates the flow-line pattern. The Support Force Glacier flow band converges from the left; a curving flow line separates it from another flow band (top left) which carries distributary ice from Foundation Ice Stream, together with the product of sheet flow across the unmapped part of the grounding line. Berkner Island appears in the top left corner of the picture. The mainland grounding line reveals a series of small off-shore ice rumples (not shown on the map) and, to the right of the picture, the deeply shadowed escarpment described by those who first confronted it as "the ice wall" (Fuchs and Hillary 1958, p. 159). Farther inland, extensive patches of crevasses indicate that this would be an unhealthy area for surface travellers.

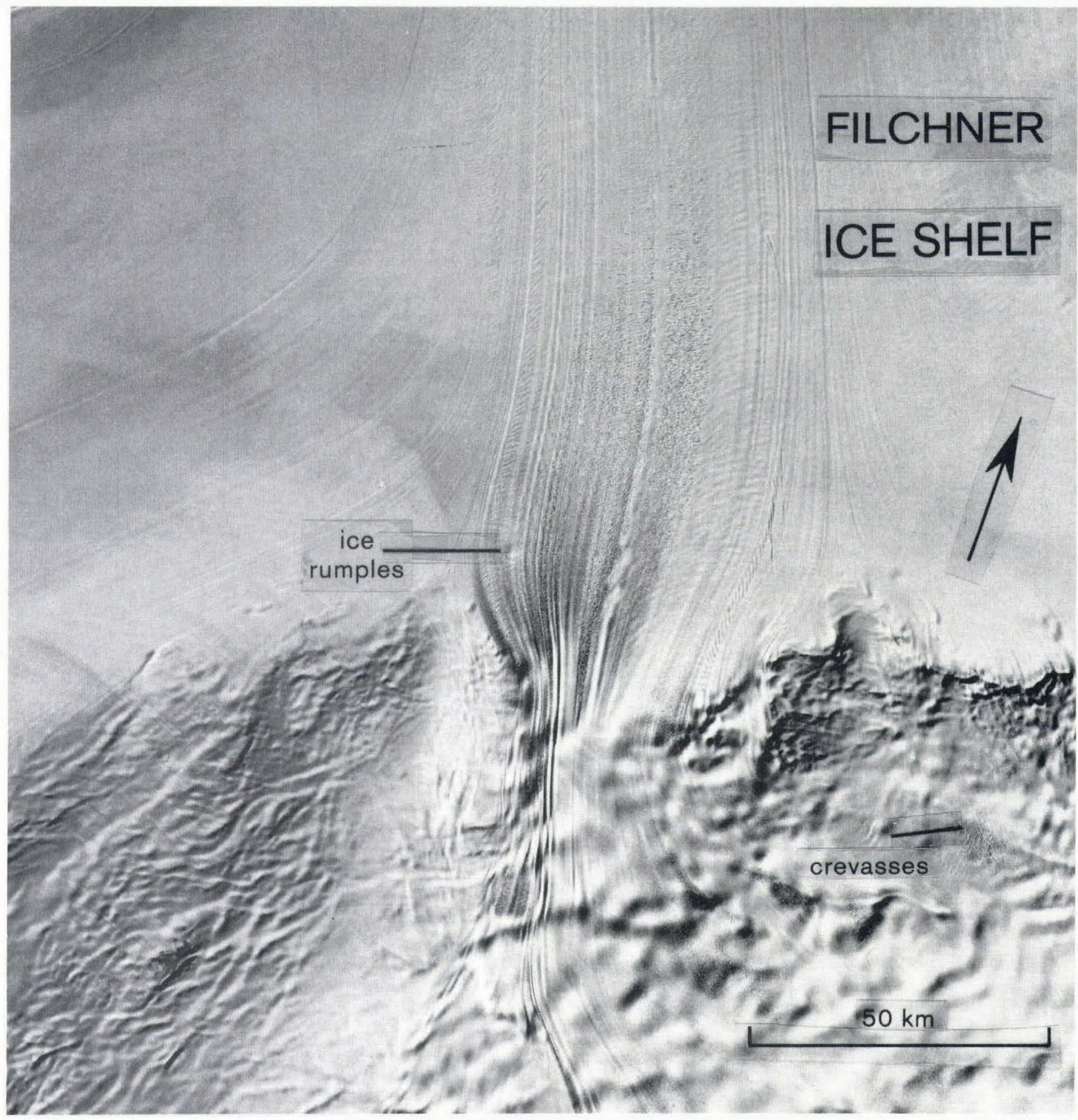

Fig. 3. Landsat-5 MSS image of the mouth of Recovery Glacier (path 173, row 119; ID 50726-08034, band $3 ; 25$ February 1986; Sun elevation $7^{\circ}$, Sun azimuth $102^{\circ}$ ). 
TABLE I. RECENT ESTIMATES OF MASS FLUX FOR THE FILCHNER-RONNE ICE SHELF DRAINAGE BASIN

\begin{tabular}{|c|c|c|c|c|c|}
\hline \multirow[t]{2}{*}{ Source } & $\begin{array}{l}\text { nland ice-sheet } \\
\text { drainage area }\end{array}$ & $\begin{array}{l}\text { Balance flux } \\
\text { at grounding } \\
\text { line }\end{array}$ & $\begin{array}{l}\text { Accumulation } \\
\text { on ice shelf/ } \\
\text { ice rises }\end{array}$ & $\begin{array}{l}\text { Mass flux } \\
\text { at ice } \\
\text { front }\end{array}$ & $\begin{array}{l}\text { Ice-shelf } \\
\text { bottom } \\
\text { melting }\end{array}$ \\
\hline & $10^{3} \mathrm{~km}^{2}$ & $\mathrm{Gt} \mathrm{a}^{-1}$ & $\mathrm{Gt} \mathrm{a}^{-1}$ & $\mathrm{Gt} \mathrm{a}^{-1}$ & $\mathrm{Gt} \mathrm{a}^{-1}$ \\
\hline McIntyre (1986) & 2500 & 235 & & & \\
\hline Giovinetto and Bentley (1985) & 2810 & 239 & 85 & & \\
\hline Doake (1985) & 3000 & 466 & 237 & 220 & 483 \\
\hline Radok and others (1986) & 3020 & 361 & 67 & 428 & 0 \\
\hline Lange (1987) & & & & 131 & \\
\hline
\end{tabular}

\section{MASS FLUX}

\section{Ice thickness}

Ice-thickness data have been reported by Behrendt (1962), Robin (1972), Behrendt and others (1974), Swithinbank (1977), Kohnen (1982), Stephenson and Doake (1982), Drewry (1983), Robin and others (1983), Crabtree and Doake (1986), Smith (1986), Doake (1987), and Swithinbank (1988). However, it is now generally believed that the central area of Ronne Ice Shelf, reported as being less than $200 \mathrm{~m}$ thick by Drewry (1983), Robin and others (1983), and Crabtree and Doake (1986), may in reality be more than $400 \mathrm{~m}$ thick (Lange and MacAyeal 1986, Thyssen 1986). Soundings are still very sparse, particularly for the thicker parts of the ice shelf, and it would be premature at this stage to attempt any new interpretation of the overall pattern of ice thickness.

\section{Velocity}

Ice-velocity data have been reported by Behrendt (1962), Lisignoli (1964), Southard and MacDonald (1974), Colvill (1977), Crabtree and Doake (1980), Kohnen (1982), Stephenson and Doake (1982), Lange and Kohnen (1985), Lindner and Ritter (1985), Kock and Wiegand (1986), Smith (1986), Doake (1987), and Lange (1987). Velocity measurements are still very sparse, particularly for the thicker parts of the ice shelf, and many more measurements are needed before we can plot the overall pattern of flow velocities. Meanwhile, recent attempts at modelling the velocity field (Lange and MacAyeal 1986) provide a useful guide to what to expect.

\section{Discussion}

Ice thickness and velocity provide the essential input to calculations of mass flux. Data are most needed close to the mouth or grounding line of each ice stream but, to date, the only measurements of input to the ice shelf have been made on Rutford Ice Stream (Stephenson and Doake 1982). The displacement of identifiable features, such as rifts, between sets of Landsat images recorded some years apart, can provide the basis for satisfactory first estimates of ice-stream velocity across the grounding line (Lucchitta and Ferguson 1986), but the method has yet to be applied within the area of the map. In the absence of measurements, estimates of steady-state or balance discharge have been based on extrapolations from snow-accumulation data integrated over the supposed area of each drainage basin.

Table I compares five recent estimates, rounded to three significant figures, of some of the principal terms in the mass-balance equation. McIntyre's smaller drainage basin is a result of omitting parts of the ice sheet that do not appear to drain into ice streams; he ignores sheet flow. The $7 \%$ difference in area between the analysis of Giovinetto and Bentley and that of Radok and colleagues is more disturbing, because both used the same topographic base map. Far more alarming, however, is the spread of values for balance flux across the grounding line. All authors had access to the same data but evidently used them selectively. Radok's figure is $1 \frac{1}{2}$ times that of Giovinetto and Bentley;

Doake's is almost twice as much. The spread of values for mass flux at the ice front is equally disturbing, although here we should note that different concepts are involved. Lange's figure is based on ice-velocity and thickness measurements, whereas the other two are balance-flux estimates. Radok does not specifically report a total for ice-shelf / ice-rise accumulation, but $67 \mathrm{Gt} \mathrm{a}^{-1}$ follows from his assumption that ice-shelf net bottom melting is negligible. The last column combines the effect of ice-shelf bottom freezing and bottom melting, to yield (in Doake's case) the net mass loss implied by the other quantities.

Considering the ice shelves separately brings no comfort. Whereas McIntyre finds that the balance flux into Ronne Ice Shelf is equal to the balance flux into Filchner Ice Shelf, Giovinetto and Bentley conclude that $67 \%$ of the inland ice mass flows into Ronne Ice Shelf. Neither source makes allowance for any contribution by Foundation Ice Stream to Filchner Ice Shelf.

\section{CONCLUSION}

The spread of all these estimates underlines the very great need for field measurements tied to reliable maps that show ice divides, flow lines, flow bands, and other significant features. Even though it can be measured, we are a long way from any consensus on the amount of snow accumulation. The bottom-melting term in the mass-balance equation is of course the least accessible to direct measurement and evidently even farther from consensus. Doake (1985) believes that it exceeds in volume the total input across the whole length of the grounding line. If true, it would follow that in the Filchner-Ronne Ice Shelf system no ice from the inland ice sheet ever reaches the ice front. While in principle we have nothing against speculation, reluctantly we can only conclude that glaciological estimates of the net mass balance of the ice sheet are premature and, at this stage, impossible to evaluate.

\section{REFERENCES}

Behrendt, J.C. 1962. Geophysical and glaciological studies in the Filchner Ice Shelf area of Antarctica. J. Geophys. Res., 67(1), 221-234.

Behrendt, J.C., J.R. Henderson, L. Meister, and W.L. Rambo. 1974. Geophysical investigations of the Pensacola Mountains and adjacent glacierized areas of Antarctica. U.S. Geol. Surv. Prof. Pap., 844.

Blaiklock, K.V., D.G. Stratton, and J.H. Miller. 1966. Survey. Trans-Antarctic Expedition 1955-58. Scientific Rep., 15.

Collins, I.F., and I.R. McCrae. 1985. Creep buckling of ice shelves and the formation of pressure rollers. $J$. Glaciol., 31(109), 242-252.

Colvill, A.J. 1977. Movement of Antarctic ice fronts measured from satellite imagery. Polar Rec., 18(115), 390-394.

Crabtree, R.D., and C.S.M. Doake. 1980. Flow lines on Antarctic ice shelves. Polar Rec., 20(124), 31-37. 
Crabtree, R.D., and C.S.M. Doake. 1986. Radio-echo investigations of Ronne Ice Shelf. Ann. Glaciol., 8, 37-41.

Doake, C.S.M. 1985. Antarctic mass balance: glaciological evidence from Antarctic Peninsula and Weddell Sea sector. In Glaciers, Ice Sheets, and Sea Level: Effect of a $\mathrm{CO}_{2}$-induced Climatic Change. Report of a Workshop held in Seattle, Washington September 13-15, 1984. Washington, DC, U.S. Department of Energy, 197-209.

Doake, C.S.M. 1987. Some aspects of the flow of the Ronne Ice Shelf. In Veen, C.J. van der, and J. Oerlemans, eds. Dynamics of the West Antarctic Ice Sheet. Proceedings of a Workshop held in Utrecht, May 6-8, 1985. Dordrecht, etc., D. Reidel Publishing Company, $75-98$.

Drewry, D.J., ed. 1983. Antarctica: glaciological and geophysical folio. Cambridge, University of Cambridge. Scott Polar Research Institute, sheet 4.2.

Ferrigno, J.G., and W.G. Gould. 1987. Substantial changes in the coastline of Antarctica revealed by satellite imagery. Polar Rec., 23(146), 577-583.

Fuchs, Sir V., and Sir E. Hillary. 1958. The crossing of Antarctica. The Commonwealth Trans-Antarctic Expedition 1955-58. London, Cassell.

Giovinetto, M.B., and C.R. Bentley. 1985. Surface balance in ice drainage systems of Antarctica. Antarct. J. U.S., 20(4), 6-13.

Kock, H., and A. Wiegand. 1986. Glaciological geodesy on Filchner Ice Shelf 1983-86. In Kohnen, H., comp. Filchner-Ronne-Ice-Shelf-Programme. Report No. 3. Bremerhaven, Alfred-Wegener-Institute for Polar and Marine Research, 37-42.

Kohnen, H. 1982. Glaciological investigations in the frontal zone of the Filchner and Ronne ice shelves. Ann. Glaciol., 3, 160-165.

Lange, M.A. 1987. Quantitative estimates of the mass flux and ice movement along the ice edges in the eastern and southern Weddell Sea. In Veen, C.J. van der, and J. Oerlemans, eds. Dynamics of the West Antarctic Ice Sheet. Proceedings of a Workshop held in Utrecht, May 6-8, 1985. Dordrecht, etc., D. Reidel Publishing Company, 57-74.

Lange, M.A., and H. Kohnen. 1985. Ice front fluctuations in the eastern and southern Weddell Sea. Ann. Glaciol., 6, 187-191.

Lange, M.A., and D.R. MacAyeal. 1986. Numerical models of the Filchner-Ronne Ice Shelf: an assessment of reinterpreted ice thickness distributions. J. Geophys. Res., 91(B10), 10457-10462.

Lindner, K., and B. Ritter. 1985. Geodätische Arbeiten auf den Filchner-Ronne- und Ekström-Schelfeisen 1979 bis 1982. Polarforschung, 55(1), 1-26.

Lisignoli, C.A. 1964. Movement of the Filchner Ice Shelf, Antarctica. Trans. Am. Geophys. Union, 45(2), 391-397.

Lucchitta, B.K., and H.M. Ferguson. 1986. Antarctica: measuring glacier velocity from satellite images. Science, 234(4780), 1105-1108.

McIntyre, N. 1986. Discharge of ice into the Filchner-Ronne ice shelves. In Kohnen, H., comp.
Filchner-Ronne-Ice-Shelf-Programme. Report No. 3. Bremerhaven, Alfred-Wegener-Institute for Polar and Marine Research, 47-52.

Neuburg, H.A.C., E. Thiel, P.T. Walker, J.C. Behrendt, and N.B. Aughenbaugh. 1959. The Filchner Ice Shelf. Ann. Assoc. Am. Geogr., 49(2), 110-119.

Radok, U., T.J. Brown, D. Jenssen, I.N. Smith, and W.F. Budd. 1986. On the surging potential of polar ice streams. Part 4. Antarctic ice accumulation basins and their main discharge regions. Boulder, Cooperative Institute for Research in Environmental Sciences.

Robin, G. de Q. 1958. Glaciology III. Seismic shooting and related investigations. Norwegian-British-Swedish Antarctic Expedition 1949-52. Scientific Results, 5.

Robin, G. de Q. 1972. Radio-echo sounding applied to the investigation of the ice thickness and sub-ice relief of Antarctica. In Adie, R.J., ed. Antarctic geology and geophysics. Oslo, Universitetsforlaget, 675-682.

Robin, G de Q., C.S.M. Doake, H. Kohnen, R.D. Crabtree, S.R. Jordan, and D. Möller. 1983. Regime of the Filchner-Ronne ice shelves, Antarctica. Nature, 302(5909), 582-586.

Shabtaie, S., and C.R. Bentley. 1987. West Antarctic ice streams draining into the Ross Ice Shelf: configuration and mass balance. J. Geophys. Res., 92(B2), 1311-1336.

Smith, A.M. 1986. Ice rumples on Ronne Ice Shelf, Antarctica. Br. Antarct. Surv. Bull., 72, 47-52.

Southard, R.B., and W.R. MacDonald. 1974. ERTS-1 imagery applications in polar regions. Antarct. J. U.S., 9(3), 61-67.

Stephenson, S.N., and C.S.M. Doake. 1982. Dynamic behaviour of Rutford Ice Stream. Ann. Glaciol., 3, 295-299.

Swithinbank, C. 1977. Glaciological research in the Antarctic Peninsula. Philos. Trans. R. Soc. London, Ser. $B, 279(963), 161-183$.

Swithinbank, C. 1986. Ice rises and ice rumples. In Kohnen, H., comp. Filchner-Ronne-Ice-Shelf-Programme. Report No. 3. Bremerhaven, Alf red-Wegener-Institute for Polar and Marine Research, 11-14.

Swithinbank, C. 1988. Antarctica. In Williams, R.S., jr, and J.G. Ferrigno, eds. Satellite image atlas of glaciers of the world. Washington, DC, U.S. Government Printing Office, 1-139. (U.S. Geol. Surv. Prof. Pap. 1386-B).

Swithinbank, C., and B.K. Lucchitta. 1986. Multispectral digital image mapping of Antarctic ice features. Ann. Glaciol., 8, 159-163.

Swithinbank, C., C. Doake, A. Wager, and R.D. Crabtree. 1976. Major change in the map of Antarctica. Polar Rec., 18(114), 295-299.

Thyssen, F. 1986. The central part of the Filchner/Ronne Ice Shelf. In Kohnen, H., comp. Filchner-RonneIce-Shelf-Programme. Report No. 3. Bremerhaven, Alf red-Wegener-Institute for Polar and Marine Research, $81-83$.

U.S. Geological Survey. 1981-82. Satellite image maps 1:1000000. (a) Filchner Ice Shelf. Antarctica, 1981. (b) Berkner Island, Antarctica, 1982. (c) Ronne Ice Shelf, Antarctica, 1982. Washington, DC, U.S. Geological Survey. 